\title{
Development of Nano Poly(3-methyl thiophene)/Multiwalled Carbon Nanotubes Sensor for the Efficient Detection of Some Pesticides
}

\author{
Palaniappan Abirama Sundari and Paramasivam Manisankar* \\ Research Scholar, Department of Industrial Chemistry, School of Chemistry, \\ Alagappa University, Karaikudi 630003 Tamil Nadu, India
}

\begin{abstract}
Foi construído um eletrodo baseado em eletrodo de carbono vítreo modificado por um filme de nanotubos de carbono de paredes múltiplas ((MWCNTs)/poli(3-metil tiofeno, P3MT), que foi usado na determinação diferentes classes de pesticidas por voltametria de redissolução de onda quadrada. Inclui-se herbicidas (isoproturon), inseticidas (voltage, cipermetrina, deltametrina, fenvalerato), e acaricidas (dicofol). O comportamento eletroquímico dos pesticidas selecionados foi investigado na superfície do nanocomposito P3MT/MWCNT/GCE, em pH 1, 4, 7, 9,2 e 13. Os voltamogramas cíclicos do isoproturon (ISO) e voltage (VOL) exibiram picos de oxidação bem definidos em $\mathrm{pH}$ 1, enquanto os outros exibiram pico de redução em $\mathrm{pH}$ 13. A determinação por voltametria de redissolução de onda quadrada dos pesticidas acima citados foi desenvolvida no mesmo sistema modificado e baixos limites de detecção foram obtidos. O procedimento analítico proposto foi aplicado em águas naturais aditivadas com os pesticidas selecionados para validar o procedimento desenvolvido.
\end{abstract}

A modified electrode fabricated by coating multiwalled carbon nanotubes (MWCNTs)/poly(3methyl thiophene, P3MT) film on a glassy carbon electrode (GCE) and was used for the adsorptive stripping voltammetric determination of different classes of pesticides. These include herbicide (isoproturon), insecticides (voltage, cypermethrin, deltamethrin, fenvalerate) and an acaricide (dicofol). Electrochemical behaviour of all the selected pesticides was investigated on P3MT/ MWCNT/GCE nano composite surface at selected $\mathrm{pHs}$ 1, 4, 7, 9.2 and 13. In cyclic voltammetry, isoproturon (ISO) and voltage (VOL) exhibited one well-defined oxidation peak at $\mathrm{pH} 1$, while remaining pesticides gave one reduction peak at $\mathrm{pH}$ 13. Adsorptive stripping voltammetric determination of above-said pesticides was developed on the same modified system and lowest detection limits were achieved. The proposed analytical procedure was applied to natural water samples spiked with the selected pesticides to validate the developed stripping procedure.

Keywords: nano sensor, poly(3-methyl thiophene), herbicide, insecticide, acaricide

\section{Introduction}

Since the discovery of carbon nanotubes (CNTs) in $1991,{ }^{1}$ they have been considered one of the most promising materials for various applications. In recent years, CNTs have been applied in various fields such as energy storage, ${ }^{2}$ actuators, ${ }^{3}$ and sensors. ${ }^{4}$ Especially, it opens a new door for electroanalytical chemistry field because of its large specific surface area and good capability of electron transfer. It has been reported that CNTs modified electrodes were successfully applied to determine many biological and organic molecules such as ascorbic acid and uric acid, ${ }^{5} \mathrm{NADH},{ }^{6}$ amino acids,${ }^{7}$ rutin, ${ }^{8,9}$

*e-mail: pms11@rediffmail.com hydrazine, ${ }^{10} \mathrm{H}_{2} \mathrm{O}_{2},{ }^{11}$ adenine, and guanine. ${ }^{12,13}$ In recent years, conducting polymer/CNTs-modified electrodes have been of great interest in electrocatalysis reactions because of their unique chemical and electrochemical properties. It has also been demonstrated that the incorporation of CNTs into conducting polymer-modified electrode possess the properties of individual components with a synergistic effect that would be useful for numerous applications. ${ }^{14-21}$ Among the conducting polymers known to date, poly(3-methylthiophene) (P3MT) is a widely investigated electronically conducting polymer, which can be easily electrodeposited onto the electrode surface by electrooxidation of its monomer. The use of P3MT as modified electrodes have been extensively reported and found to show excellent electrocatalytic effect on phenolic 
compounds, ${ }^{22,23}$ neurotransmitter species, ${ }^{24-27}$ amino acids, ${ }^{28}$ $\mathrm{NADH},{ }^{29}$ and a herbicide metamitron. ${ }^{30}$ In the recent past, attempts have been made to combine the properties of P3MT and MWCNTs for the effective determination of dopamine, ${ }^{31}$ and some biologically important compounds like NADH, FAD and cytochrome $c .{ }^{32}$

Environmental pollution is a serious concern in recent times due to the damage of eco system in the globe. Among the pollutants, pesticides are considered as hazardous chemicals used in agriculture. Pesticide is a substance used to kill or repel insects, weeds, bacteria, mold, or viruses. The use of pesticide raises a number of environmental concerns. Over $98 \%$ of sprayed insecticides and $95 \%$ of herbicides reach a destination other than their target species, including air, water, bottom sediments and food. ${ }^{33}$ They cause water pollution and some are persistent and contribute to soil contamination. In addition, pesticide use also reduces biodiversity and results in lower soil quality, reduced nitrogen fixation, contribute to pollinator decline, can reduce habitat, especially for birds, and can threaten endangered species. Several environmental and health problems are associated with their use. Hence the determination of pesticides in trace level becomes very important in environmental point of view. In the present work, a new P3MT/MWCNTGCE nano pesticide sensor was fabricated for the quantification of some important pesticides, isoproturon (ISO), voltage (VOL), cypermethrin (CYP), deltamethrin (DEL), fenvalerate (FEN) and dicofol (DCF).

\section{Experimental}

\section{Instrumentation and reagents}

Cyclic and differential pulse stripping voltammetric studies were performed using CHI 760C electrochemical workstation (CH Instruments, USA) coupled with a conventional three-electrode cell. The working electrode was P3MT/MWCNT/GCE, the auxiliary electrode was platinum wire and the reference electrode was $\mathrm{Ag} / \mathrm{AgCl}$. MWCNTs (I.D. $\times$ length 2-15 $\mathrm{nm} \times 1-10 \mu \mathrm{m}$, produced by arc method) purchased from Sigma-Aldrich, USA and the dispersive agent sodium dodecyl sulphate (SDS) (AR Grade) was purchased from Merck, India. Technical grade of all the selected pesticides were obtained from the Bureau of Indian Standards. $0.1 \mathrm{~mol} \mathrm{~L}^{-1}$ stock solution was made up in ethanol for all these pesticides. For studies in aqueous media, $0.1 \mathrm{~mol} \mathrm{~L}^{-1} \mathrm{H}_{2} \mathrm{SO}_{4}$ (for $\mathrm{pH} 1.0$ ), Britton Robinson Buffers (for $\mathrm{pH} 4.0,7.0,9.2$ ) and $0.1 \mathrm{~mol} \mathrm{~L}^{-1} \mathrm{NaOH}$ (for $\mathrm{pH} 13.0$ ) in $50 \%$ aqueous alcohol were used. Bench top pH meter model-Cyberscan 500 (Eutech Instrument) was used for all $\mathrm{pH}$ measurements.

\section{Modification of working electrode}

Before modification, GCE was pretreated in two ways as reported by us earlier. ${ }^{34}$ First, $1 \mathrm{mg}$ of MWCNTs was dispersed into $0.1 \mathrm{~mol} \mathrm{~L}^{-1} \mathrm{SDS}$ for $30 \mathrm{~min}$ by ultrasonic agitation to give a homogeneous MWCNTs suspension. Secondly, GCE surface was coated with $5 \mu \mathrm{L}$ of the resulting MWCNT-SDS suspension and allowed to evaporate in an oven at $50{ }^{\circ} \mathrm{C}$. P3MT was deposited by electrooxidation of $0.05 \mathrm{~mol} \mathrm{~L}^{-1}$ 3-methyl thiophene (3MT) containing $0.05 \mathrm{~mol} \mathrm{~L}^{-1}$ sodium perchlorate as a supporting electrolyte and cycling the potential between $0 \mathrm{~V}$ and $1.6 \mathrm{~V}$ on MWCNT/GCE.

\section{Real sample analysis}

In order to assess the possible applications of the proposed method in the determination of pesticides, samples were spiked with water and then analyzed using the following procedure. The water sample to be analyzed was prepared by adding known amount of ISO stock solution and pesticide-free water and then allowing them to stand $24 \mathrm{~h}$. A glass column was filled with amberlite XAD-4 resin up to a height of $20 \mathrm{~cm}$. The column was washed with ethanol, diethyl ether and distilled water. Then the spiked water was filtered through the column at an average rate of $10 \mathrm{~mL} \mathrm{~min}{ }^{-1}$. After completion of this process, the tap was closed and dichloromethane filled the column and then allowing them to stand $20 \mathrm{~min}$. Thus, the column was drained into a beaker. The extract was evaporated to dryness by gentle heating on a water bath. The residue was transferred into a $250 \mathrm{~mL}$ calibrated flask, dissolved in ethanol and made up to the mark. ISO was determined by differential pulse stripping voltammetric method. Percentage of recovery and relative standard deviations for ISO were determined for six different concentrations. Similar experiments were carried out for the other pesticides and the results are discussed in the following section

\section{Results and Discussion}

\section{Voltammetric behaviour of pesticides}

The catalytic activity of modified electrode is demonstrated in the cyclic voltammograms (CVs) recorded for all the selected pesticides in the $\mathrm{pH}$ range of 1 to 13 . When the electrode potential was scanned from 0.6 to $1.7 \mathrm{~V}$ for ISO $\left(0.99 \mathrm{~m} \mathrm{~mol} \mathrm{~L}^{-1}\right)$ and 0 to 1.3 for VOL $\left(0.99 \mathrm{mmol} \mathrm{L}^{-1}\right)$, a well-defined oxidation peak at $1.183 \mathrm{~V}$, $(291.5 \mu \mathrm{A})$ for the former and $0.856 \mathrm{~V},(301.9 \mu \mathrm{A})$ for the later in $0.1 \mathrm{~mol} \mathrm{~L}^{-1} \mathrm{H}_{2} \mathrm{SO}_{4}(\mathrm{pH} 1)$ at the scan rate of $0.1 \mathrm{~V} \mathrm{~s}^{-1}$ was noticed (Figure 1A and Figure 2A). 

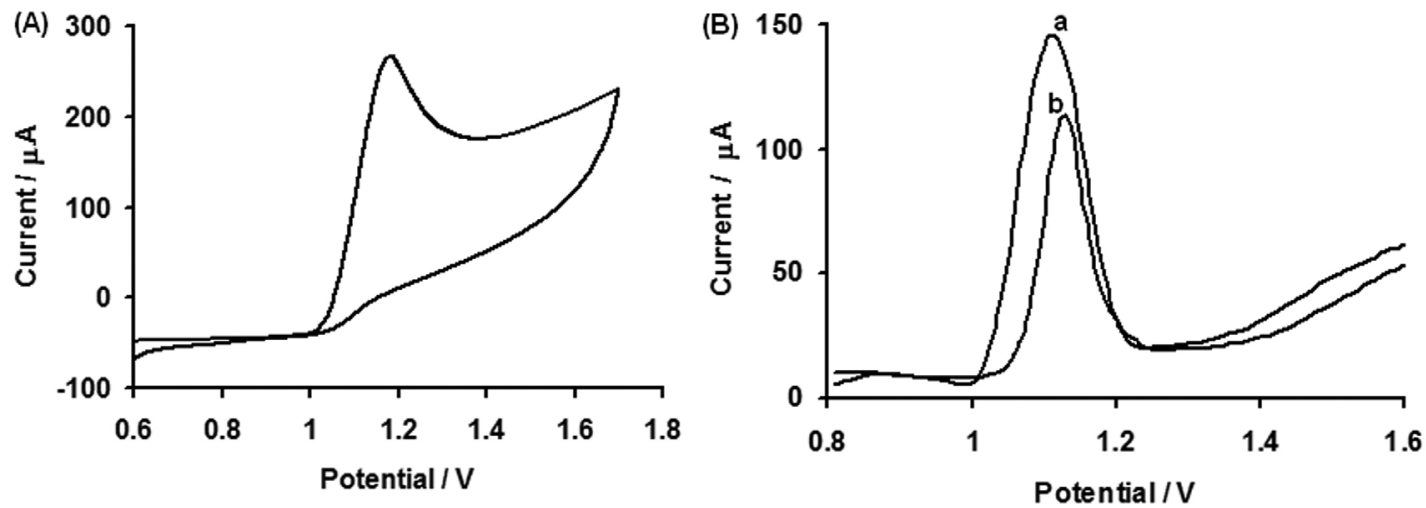

Figure 1. (A) Cyclic voltammogram of $0.99 \mathrm{mmol} \mathrm{L}^{-1} \mathrm{ISO}$, scan rate $0.1 \mathrm{~V} \mathrm{~s}^{-1}$; (B) Differential pulse stripping voltammogram of $100 \mu \mathrm{g} \mathrm{L}^{-1}$ ISO (a) conventional (b) real sample at $\mathrm{pH} 1$.
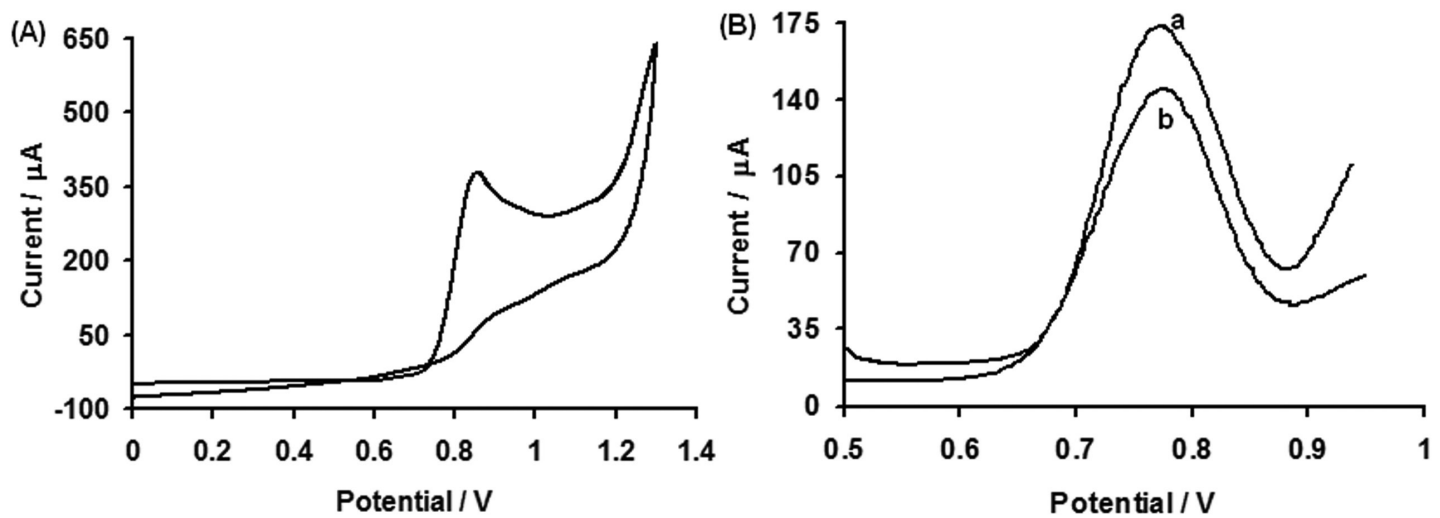

Figure 2. (A) Cyclic voltammogram of $0.99 \mathrm{mmol} \mathrm{L}^{-1} \mathrm{VOL}$, scan rate $0.1 \mathrm{~V} \mathrm{~s}^{-1}$; (B) Differential pulse stripping voltammogram of $100 \mu \mathrm{g} \mathrm{L} \mathrm{LOL}^{-1} \mathrm{VO}$ (a) conventional (b) real sample at $\mathrm{pH} 1$.

Absence of cathodic peaks in the reverse scan of both the cases indicated irreversible nature of electron transfer process. The electrochemical responses of $1 \mathrm{mmol} \mathrm{L}^{-1} \mathrm{CYP}$, DEL, FEN and $0.99 \mathrm{mmol} \mathrm{L}^{-1} \mathrm{DCF}$ in $0.1 \mathrm{~mol} \mathrm{~L}^{-1} \mathrm{NaOH}$ at the same modified electrode were investigated. Figures $3 \mathrm{~A}$ to $6 \mathrm{~A}$ show the cyclic voltammograms of CYP, DEL, FEN and $\mathrm{DCF}$ at $\mathrm{pH} 13$ at the scan rate of $0.1 \mathrm{~V} \mathrm{~s}^{-1}$. One reduction peak at $-1.381 \mathrm{~V}(312.9 \mu \mathrm{A}),-1.38 \mathrm{~V}(306.1 \mu \mathrm{A}),-1.348 \mathrm{~V}$ (320.6) and $-1.324 \mathrm{~V}(339.2 \mu \mathrm{A})$ were observed for CYP,

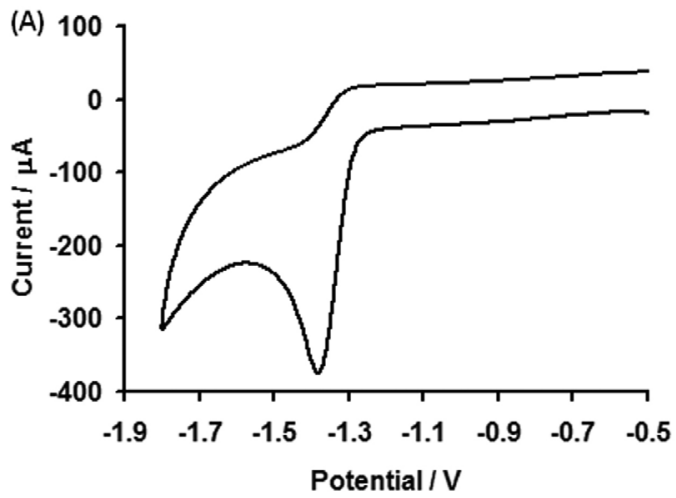

DEL, FEN and DCF, respectively. On the reversal scan, no oxidation peak appears, indicating the complete irreversible reduction of above pollutants.

Further, the effect of scan rate on the electrooxidation and reduction of selected pesticides at the modified electrode was investigated by cyclic voltammetry. Correlation of peak current $\left(i_{\mathrm{p}}\right)$ with sweep rate $(v)$ and square root of sweep rate $\left(v^{1 / 2}\right)$ resulted that the peak current increases linearly with $v$ up to $v<0.150 \mathrm{~V} \mathrm{~s}^{-1}$,

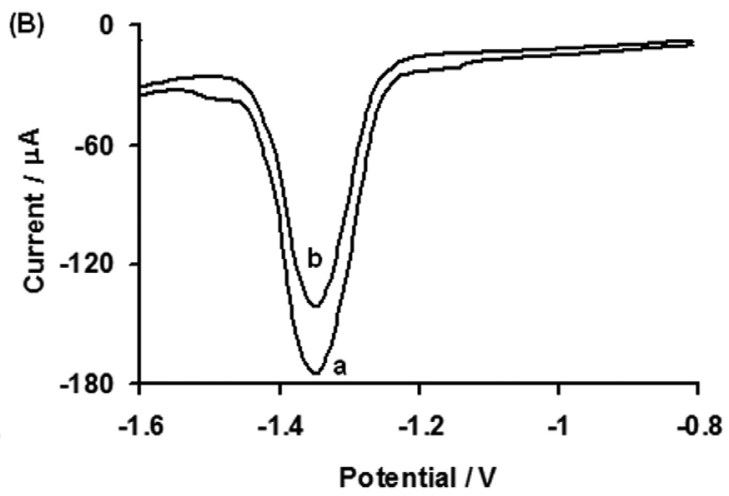

Figure 3. (A) Cyclic voltammogram of $1 \mathrm{mmol} \mathrm{L}^{-1} \mathrm{CYP}$, scan rate $0.1 \mathrm{~V} \mathrm{~s}^{-1}$; (B) Differential pulse stripping voltammogram of $100 \mu \mathrm{g} \mathrm{L} \mathrm{CYP}^{-1}$ (a) conventional (b) real sample at $\mathrm{pH} 13$. 

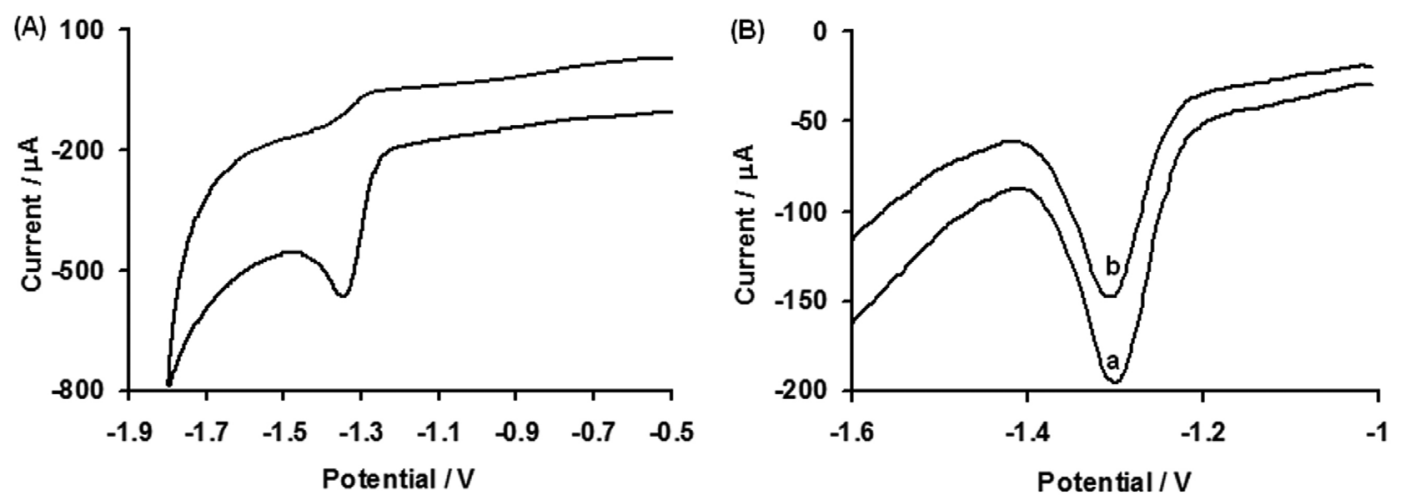

Figure 4. (A) Cyclic voltammogram of $1 \mathrm{mmol} \mathrm{L}^{-1} \mathrm{DEL}$, scan rate $0.1 \mathrm{~V} \mathrm{~s}^{-1}$; (B) Differential pulse stripping voltammogram of $100 \mu \mathrm{g} \mathrm{L} \mathrm{L}^{-1} \mathrm{DEL}$ (a) conventional (b) real sample at $\mathrm{pH} 13$.
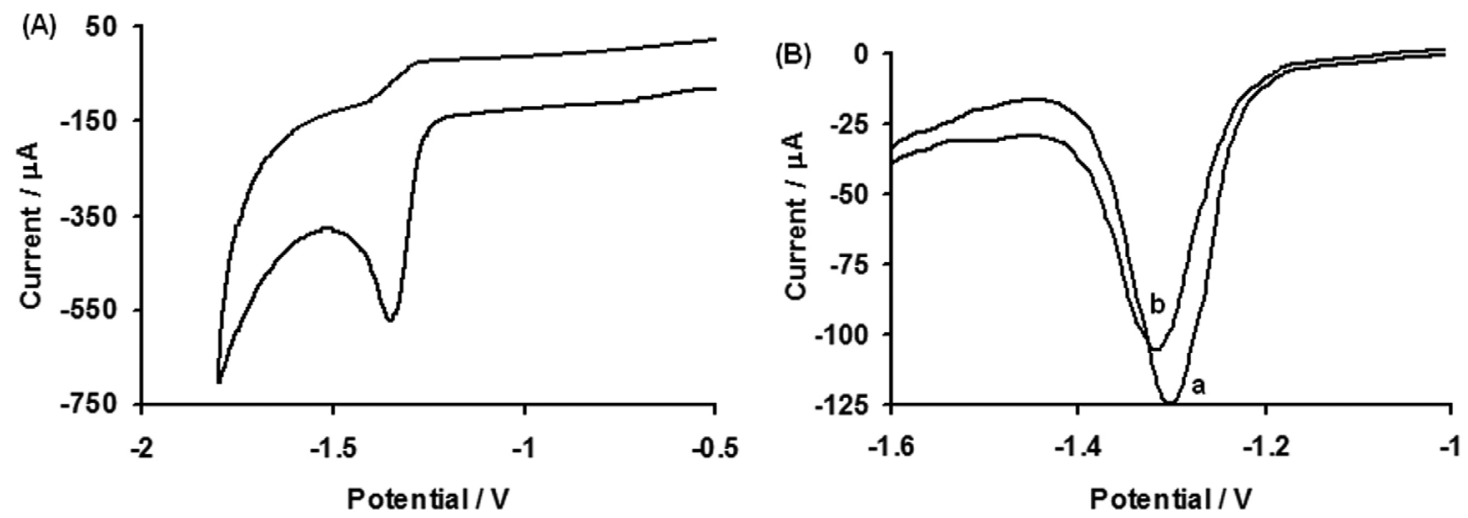

Figure 5. (A) Cyclic voltammogram of $1 \mathrm{mmol} \mathrm{L}^{-1} \mathrm{FEN}$, scan rate $0.1 \mathrm{~V} \mathrm{~s}^{-1}$; (B) Differential pulse stripping voltammogram of $100 \mu \mathrm{g} \mathrm{L} \mathrm{L}^{-1} \mathrm{FEN}$ (a) conventional (b) real sample at $\mathrm{pH} 13$.
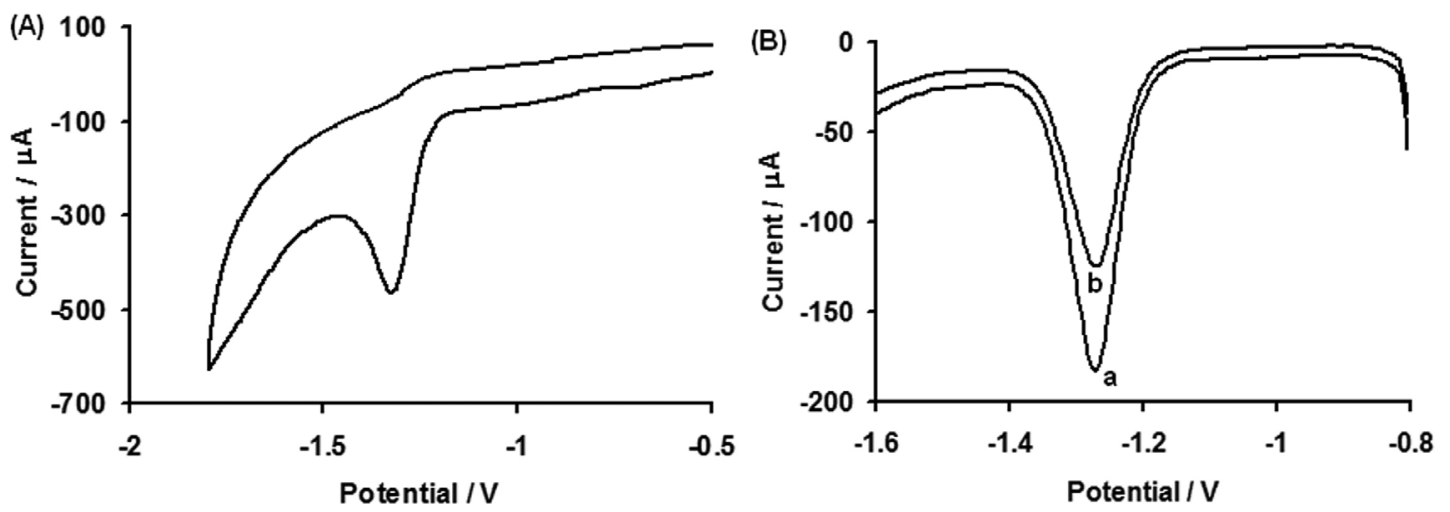

Figure 6. (A) Cyclic voltammogram of $0.99 \mathrm{mmol} \mathrm{L}^{-1} \mathrm{DCF}$, scan rate $0.1 \mathrm{~V} \mathrm{~s}^{-1}$; (B) Differential pulse stripping voltammogram of $100 \mu \mathrm{g} \mathrm{L}{ }^{-1} \mathrm{DCF}$ (a) conventional (b) real sample at $\mathrm{pH} 13$.

while at higher scan rates a linear dependence of peak currents on $v^{1 / 2}$ is observed with the straight line having good correlation coefficient ( 0.98 to 0.99 ). The plot of $\log \mathrm{i}_{\mathrm{p}} v s . \log v$ correlation equation also led to a straight line (with a slope value of 0.54 to 0.62 ). All the above facts confirmed diffusion controlled adsorption nature of above said redox processes. Furthermore, fractional $\alpha$ value $(0.47$ to 0.78 ) indicated, irreversible electron transfer nature for the above process. The significant improvement of peak current together with the sharpness of anodic and cathodic peaks clearly demonstrate that the modified film acts as an efficient electron transfer mediator in the electrocatalytic oxidation and reduction of aforementioned pesticides, leading to a considerable improvement in the analytical sensitivity. Table 1 exhibited peak currents obtained in different modified systems by cyclic voltammetric method. From that table, it can be inferred that the peak current obtained in MWCNT/GCE and P3MT/GCE systems is very 
Table 1. Comparison of cyclic voltammetric results at different modified systems at the scan rate of $0.1 \mathrm{~V} \mathrm{~s}^{-1}$

\begin{tabular}{|c|c|c|c|c|c|c|c|}
\hline \multirow[t]{2}{*}{ Pesticides } & \multirow{2}{*}{$\begin{array}{l}\text { Concentration, } \\
\text { mmol L-1 }\end{array}$} & \multicolumn{2}{|c|}{ P3MT/GCE } & \multicolumn{2}{|c|}{ MWCNT/GCE } & \multicolumn{2}{|c|}{ P3MT/MWCNT/GCE } \\
\hline & & $\mathrm{E}_{\mathrm{P}}(\mathrm{V})$ & $\mathrm{i}_{\mathrm{P}}(\mu \mathrm{A})$ & $\mathrm{E}_{\mathrm{P}}(\mathrm{V})$ & $\mathrm{i}_{\mathrm{P}}(\mu \mathrm{A})$ & $\mathrm{E}_{\mathrm{P}}(\mathrm{V})$ & $\mathrm{i}_{\mathrm{P}}(\mu \mathrm{A})$ \\
\hline ISO & 0.99 & 1.218 & 23.36 & 1.090 & 25.25 & 1.183 & 291.5 \\
\hline VOL & 0.99 & 0.861 & 11.85 & 0.825 & 12.34 & 0.856 & 301.9 \\
\hline CYP & 0.99 & -1.415 & 49.72 & -1.440 & 56.30 & -1.381 & 312.9 \\
\hline DEL & 1 & -1.407 & 14.93 & -1.490 & 16.00 & -1.380 & 306.1 \\
\hline FEN & 1 & -1.370 & 14.01 & -1.440 & 15.36 & -1.348 & 320.6 \\
\hline DCF & 1 & -1.354 & 20.40 & -1.398 & 23.71 & -1.324 & 339.2 \\
\hline
\end{tabular}

low compared to P3MT/MWCNT/GCE. This is because of synergistic effect between both the individual components, which greatly increases the peak current of all the selected pesticides.

\section{Optimization of experimental conditions}

Differential pulse stripping voltammetry was used in the voltammetric measurement owing to its good sensitivity and resolving power. The experimental conditions were optimized.

\section{Influence of accumulation parameters}

It has been mentioned that the oxidation and reduction processes of all pesticides at the modified electrode was an adsorption process which is controlled by diffusion, and hence pesticides might be accumulated on electrode surface through hydrophobic interaction between the pesticides and the surfactant layer. Thus, the influence of accumulation time on peak currents of pesticides should be non-negligible. Peak current increases apparently with the increase of accumulation time. After a series of stripping voltammograms, $10 \mathrm{~s}$ for ISO, VOL and FEN, $5 \mathrm{~s}$ for CYP, DEL and DCF was chosen as the optimal accumulation time. The dependence of accumulation potential was also studied. It was varied from -0.3 to $0.3 \mathrm{~V}$ for all the selected pesticides and best accumulation potential was found to be $0.2,0.1$, $-0.1,-0.15,0.1$ and $0 \mathrm{~V}$ for ISO, VOL, CYP, DEL, FEN and DCF, respectively. These values showed that the adsorbed species are most probably neutral molecules of pesticides.

\section{Characterization of modified electrode}

\section{$X$-ray diffraction studies}

XRD pattern of MWCNT/GCE is provided in Figure 7A that shows substantial amorphous nature and that of P3MT/ GCE (Figure 7B) exhibits also an amorphous nature. Figure 7C explains XRD pattern of P3MT/MWCNT/GCE, which also shows amorphous nature. Althogh, its morphology is unquestionably distinct from XRD patterns of individual films, i.e., (Figures 7A and 7B).
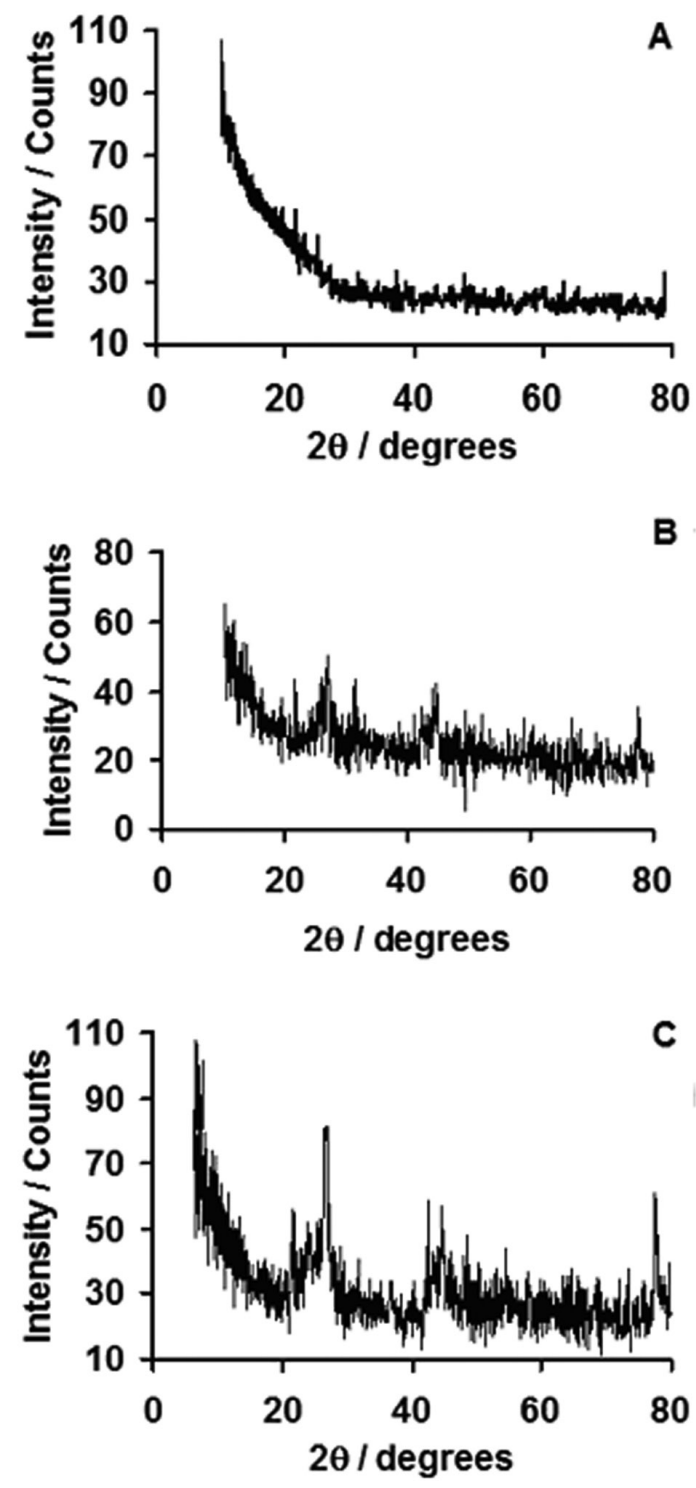

Figure 7. X-ray diffraction patterns of (A) MWCNT/GCE; (B) P3MT/ GCE; (C) P3MT/MWCNT/GCE. 


\section{Scanning electron microscopic studies}

SEM micrographs of MWCNT/GCE and P3MT/ GCE are provided in Figures 8A and 8B. SEM images of MWCNT modified film showed tubular morphology and that of P3MT modified film showed uniformly distributed spherical shaped particulates. Figure 8C, showed polymer molecules deposited on the surface of tubes affirmed the polymerization of P3MT on MWCNTs. Interestingly, the SEM image of P3MT/MWCNT modified film shows spherical shaped polymers reinforced into the MWCNTs. This observation suggests the formation of polymer embedded MWCNT nanocomposite structures on the electrode surface. The average tube size of the modified surface was approximated $50 \mathrm{~nm}$.

Adsorption of pesticides molecules was done at their maximum accumulation conditions owing to the diffusion controlled adsorption nature of pesticide molecules. The change in surface morphology was understood through scanning electron microscopic studies. Figures 8D-8I show the SEM micrographs of pesticide adsorbed modified surfaces. ISO molecules adsorbed as cubes on the modified electrode surface is well evident from Figure 8D. Uniform adsorption of VOL could be seen from Figure 8E. Dense, mixed needle like structure in Figure 8F exhibits CYP adsorbed modified surface. Figure $8 \mathrm{G}$ shows ball like particles dispersed in a random manner that confirms the presence of DEL on the modified system. Figure $8 \mathrm{H}$ indicates cloudy like appearance confirming the adsorption process of FEN. DCF molecules are adsorbed uniformly as flakes on the surface of modified system as displayed in Figure 8I.

Figures 9 show cyclic voltammograms obtained at the modified surface before and after adsorption. From this, one can find, there is no response in the cyclic voltammograms in buffer solutions 1 and 13 alone, i.e., in the absence of pesticide molecules (Figures 9A and B). But after $10 \mathrm{~min}$
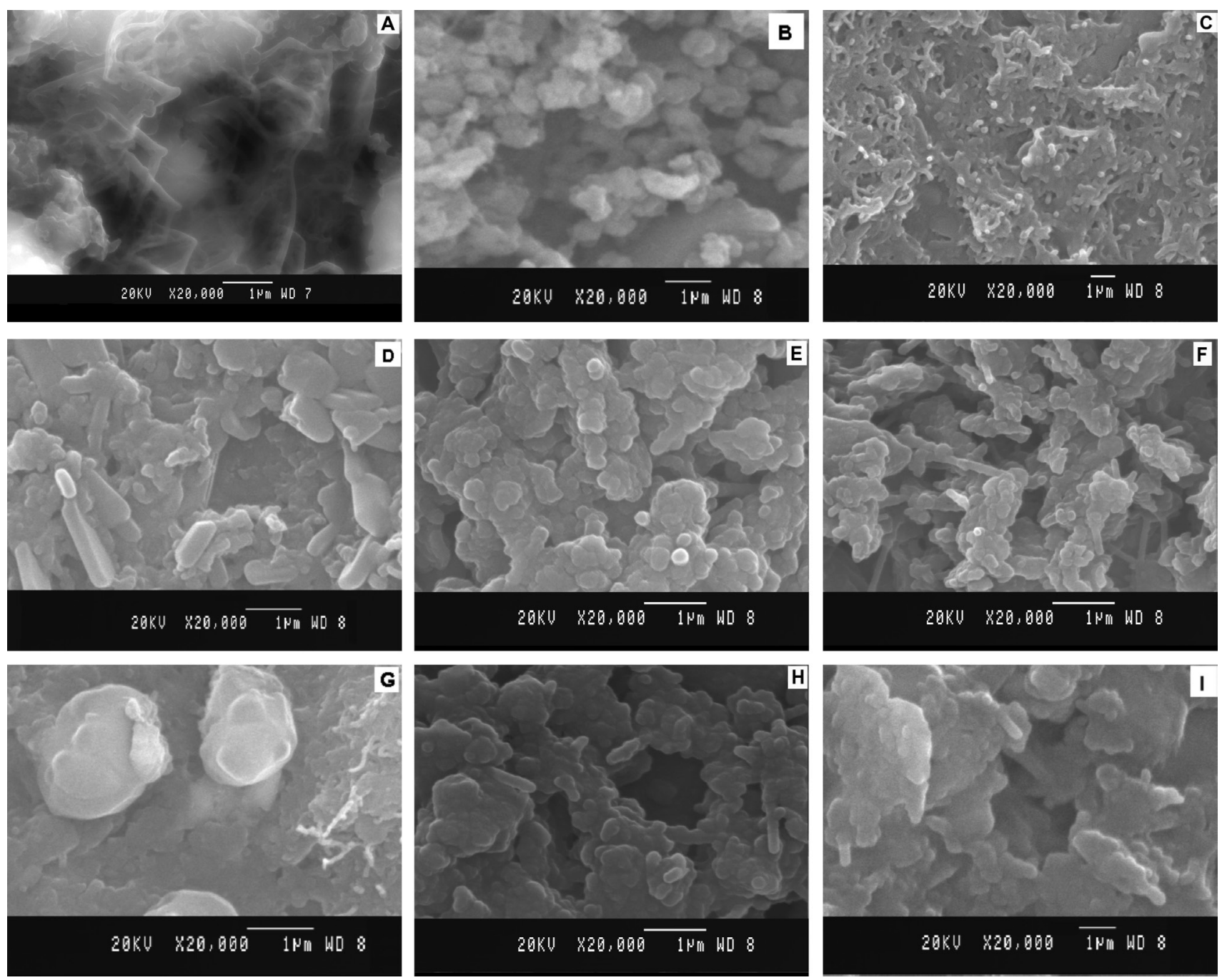

Figure 8. Scanning electron micrographs of (A) MWCNT/GCE; (B) P3MT/GCE (C) P3MT/MWCNT/GCE; and (D) ISO; (E) VOL; (F) CYP; (G) DEL; (H) FEN adsorbed; (I) DCF adsorbed on P3MT/MWCNT/GCE. 

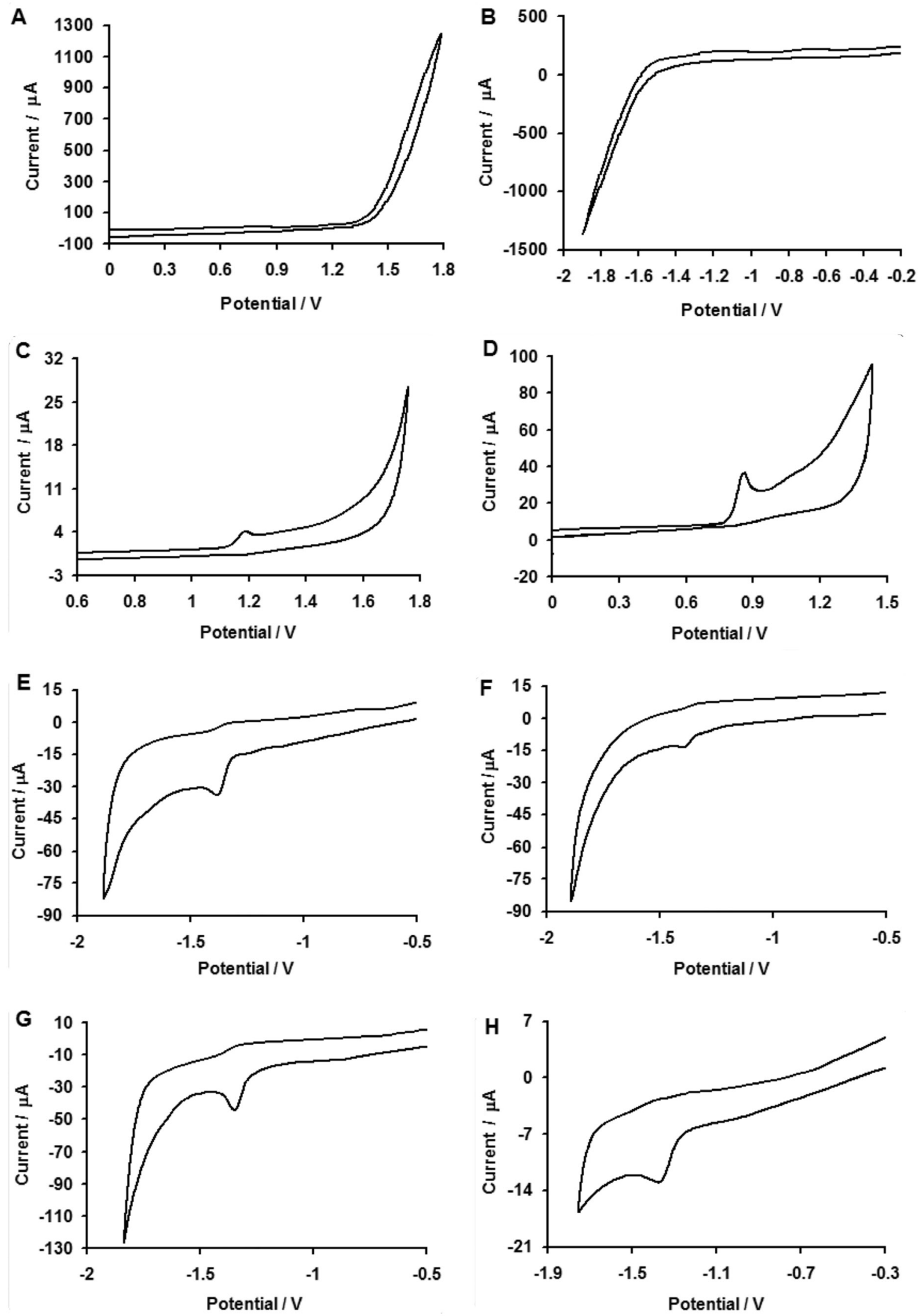

Figure 9. Cyclic voltammograms of (A) Zero concentration of pesticide (pH 1); (B) as (A) (pH 13); and (C) ISO, (D) VOL, (E) CYP, (F) DEL, (G) FEN and $(\mathrm{H}) \mathrm{DCF}$, after $10 \mathrm{~min}$ adsorption in the respective pesticide solution. 
of adsorption, there is a better response (with small peak currents) of pesticide molecules as seen in the respective buffer solution (Figures 9C-H).

\section{Influence of stripping parameters}

Analytical signal for all the selected pesticides were optimized by changing the following parameters, initial scan potential, amplitude, pulse width, and keeping other parameters such as scan increment, sampling width, pulse period and quiet time, constant. Adsorptive stripping voltammetry enhances the scope of stripping measurements towards numerous trace analysis. Depending on the redox activity of compound, the quantification of adsorbed organic analyte may either proceed through oxidation or reduction. Initial scan potential was changed from 0 to $0.9 \mathrm{~V}$ for ISO, 0 to 0.6 for $\mathrm{VOL},-0.5 \mathrm{~V}$ to $-1.0 \mathrm{~V}$ for CYP and DCF, -0.5 to $-1.2 \mathrm{~V}$ for DEL and FEN. Peak current response was found to be maximum in the range of $0.8,0.5$ for ISO and VOL, -0.8 for CYP and FEN, -1.0 for DEL and DCF respectively. For pulse amplitude study between 0.010 and $0.2 \mathrm{~V}$, linear relationship was noticed between peak current and applied pulse amplitudes from 0.010 to $0.090 \mathrm{~V}$. Hence pulse amplitude of $0.090 \mathrm{~V}$ was chosen further due to the maximum current response in the linear range. Effect of pulse width has demonstrated that the stripping peak current was observed to decrease with increasing pulse width from 0.010 to $0.150 \mathrm{~s}$ and maximum of the peak current was reached in the pulse width of $0.05 \mathrm{~s}$ for all the reported pesticides.

\section{Analytical determination of pesticides}

\section{Calibration plot}

Under optimized conditions, differential pulse stripping voltammograms of all the above said pesticides are shown in Figure $1 \mathrm{~B}(\mathrm{a})-6 \mathrm{~B}(\mathrm{a})$. The linear region was from 8.0 to $25 \times 10^{4} \mathrm{ng} \mathrm{L}^{-1}$ for ISO, 8.1 to $25 \times 10^{4} \mathrm{ng} \mathrm{L}^{-1}$ for VOL, 1.5 to $25 \times 10^{4} \mathrm{ng} \mathrm{L}^{-1}$ for CYP, 1.9 to $25 \times 10^{4} \mathrm{ng} \mathrm{L}^{-1}$ for DEL, 6.1 to $25 \times 10^{4} \mathrm{ng} \mathrm{L}^{-1}$ for FEN, 5.4 to $25 \times 10^{4} \mathrm{ng} \mathrm{L}^{-1}$ for DCF. The minimum concentration value (detection limit) reported here is lower than other chromatographic methods. The analytical characteristics observed during the validation of this method were then compared with those obtained in earlier reports (Table 2).

\section{Validation of the method}

Validation of the proposed method for the quantitative estimation of pesticides was examined via evaluation of the specificity, stability and precision of the method as follows.

\section{Specificity}

Specificity of optimized procedure for the evaluation of pesticides was investigated by observing any interference encountered from endogenous substances present in it, which may affect the specificity of proposed method. Tolerance limit was defined as the concentrations of foreign substances, which gave an error less than $\pm 5.0 \%$ in the detection of pesticides. The effect of interferences (anions such as $\mathrm{Cl}^{-}, \mathrm{Br}^{-}, \mathrm{I}^{-}, \mathrm{SO}_{4}{ }^{2-}, \mathrm{NO}_{3}^{-}$was examined by carrying out the determination of $250 \mu \mathrm{g} \mathrm{L}^{-1}$ in the presence of different concentrations $\left(150-300 \mu \mathrm{g} \mathrm{L}^{-1}\right)$ of the interferences.

\section{Stability and reproducibility of the modified electrode}

The long-term stability of modified electrode was investigated by measuring the current response at a fixed pesticide concentration. Modified electrode was prepared and stored in air. The experimental conditions showed that the current response only deviates by $2.3 \%$, suggesting that the modified electrode possess good stability for

Table 2. Comparison limits of detection (LOD) with available methods

\begin{tabular}{|c|c|c|c|c|c|c|c|}
\hline \multirow{2}{*}{ Sample No. } & \multirow{2}{*}{ Techniques } & \multicolumn{6}{|c|}{ Pesticides } \\
\hline & & ISO & VOL & CYP & DEL & FEN & DCF \\
\hline 1 & Matrix solid phase dispersion ${ }^{35}\left(\mu \mathrm{g} \mathrm{kg}^{-1}\right)$ & - & 9 & - & - & - & - \\
\hline 2 & Gas chromatography-mass spectrometry ${ }^{36}\left(\mu \mathrm{g} \mathrm{kg}^{-1}\right)$ & - & 0.106 & 0.495 & 0.106 & 0.06 & - \\
\hline 3 & $\begin{array}{l}\text { Coupling single-drop microextraction with gas chromatography-mass } \\
\text { spectrometry }{ }^{37}\left(\mathrm{ng} \mathrm{mL}^{-1}\right)\end{array}$ & - & - & - & - & - & 0.2 \\
\hline 4 & Gas chromatography-ion trap mass spectrometry ${ }^{38}\left(\mathrm{mg} \mathrm{kg}^{-1}\right)$ & - & - & - & 0.013 & - & - \\
\hline 5 & $\begin{array}{l}\text { HPLC with fluorescence detection combined with UV decomposition } \\
\text { and post column derivatization }{ }^{39}\left(\mathrm{~m} \mathrm{~kg} \mathrm{k}^{-1}\right)\end{array}$ & 0.002 & - & - & - & - & - \\
\hline 6 & Gas chromatography-time of flight mass spectrometry ${ }^{40}\left(\mathrm{ng} \mathrm{mL}^{-1}\right)$ & - & - & 10 & - & 3 & 3 \\
\hline 7 & Microwave assisted headspace solid-phase microextraction ${ }^{41}\left(\mathrm{ng} \mathrm{mL}^{-1}\right)$ & - & - & 1 & 2.6 & 1.3 & - \\
\hline 8 & Liquid chromatography-tandem mass spectrometry ${ }^{42}\left(\mathrm{ng} \mathrm{L}^{-1}\right)$ & 97 & & - & - & - & - \\
\hline 9 & Voltammetric method (ng L $\left.{ }^{-1}\right)$ [This work] & 8.0 & 8.1 & 1.5 & 1.9 & 6.1 & 5.4 \\
\hline
\end{tabular}


the determination of all pesticides. Precision of this method was evaluated by repeating six experiments for six consecutive days for same concentration of pesticide solution. Relative standard deviation value was found to be $2.08 \%$. The electrode-to-electrode reproducibility of this method was examined on six modified electrodes fabricated individually and R.S.D. of the four average peak currents of $0.1 \mathrm{mmol} \mathrm{L}^{-1}$ of pesticide was calculated to be $1.92 \%$, which demonstrates good reproducibility of present method at this electrode.

\section{Analytical applications}

\section{Recovery studies in real samples}

We examined the applicability of modified electrode for the determination of pesticides in water samples. The recoveries indicate that, the accuracy of the proposed voltammetric method is good. Precision and accuracy of this method was determined after dosing known amount of analytes into environmental sample solution. The precision of all pollutants was calculated from six repeated analyses at different intervals. The percentage of recoveries with standard error of all the insecticides is presented in Table 3. The stripping voltammograms thus obtained are given in Figures $1 \mathrm{~B}(\mathrm{~b})-6 \mathrm{~B}(\mathrm{~b})$ on the same system. Based on this study, it is possible to conclude that these stripping voltammetric measurements are efficient in the determination of all type pesticides.

Table 3. Percentage recovery of selected pesticides from water samples

\begin{tabular}{lcccc}
\hline Pesticides & $\begin{array}{c}\text { Spiked } \\
\mu \mathrm{g} \mathrm{L}^{-1}\end{array}$ & Found & $\begin{array}{c}\text { Recovery } \\
\%\end{array}$ & RSD $^{*}$ \\
\hline \multirow{2}{*}{ ISO } & 25 & 23.10 & 92.40 & 2.1 \\
& 100 & 91.25 & 91.25 & 1.6 \\
\hline \multirow{2}{*}{ VOL } & 25 & 23.63 & 94.52 & 3.1 \\
& 100 & 93.98 & 93.98 & 2.3 \\
\hline \multirow{2}{*}{ CYP } & 25 & 22.49 & 89.96 & 1.5 \\
& 100 & 89.04 & 89.04 & 2.5 \\
\hline \multirow{2}{*}{ DEL } & 25 & 21.94 & 87.76 & 1.9 \\
& 100 & 86.95 & 86.95 & 2.6 \\
\hline \multirow{2}{*}{ FEN } & 25 & 22.13 & 88.52 & 1.6 \\
& 100 & 87.15 & 87.15 & 3.0 \\
\hline
\end{tabular}

$*_{n}=6$.

\section{Conclusions}

Glassy carbon electrode modified with P3MT/MWCNT film has been used successfully for the electrocatalytic oxidation and reduction of some pesticides in acidic and alkaline solutions. The obtained modified film exhibits individual properties of both the constituents, i.e., conducting polymer and MWCNTs. Herein, 3MT polymerizes on the fine matrix of MWCNTs and the same was confirmed through SEM micrographs. The results indicate that the modified electrode facilitates the determination of pesticides with good sensitivity and reproducibility compared to similar conducting polymer/ MWCNT based electrodes or other instrumental methods. This sensor can be used for the stripping voltammetric determination of selected analytes as low as 1.5-8.1 $\mathrm{ng} \mathrm{L}^{-1}$ with good reproducibility with little fouling effects of analytes. This modified electrode has been used for the determination of all the above said pesticides in spiked water samples. Our observations demonstrate that this conducting polymer/MWCNT modified electrode is a stable and reproducible with high sensitivity as well as lower detection limit, which could have promising applications in sensor. The same method offers the advantages of accuracy and time saving as well as simplicity of reagents and apparatus. In addition, the results obtained in the analysis of pesticides in water samples demonstrate that, the applicability of this method for real sample analysis. In general the proposed stripping voltammetric method is sensitive than majority of the available methods.

\section{Acknowledgements}

The authors would like to thank Department of Science and Technology (DST), New Delhi, India for their financial support to our project (Vide Project No. SR/S1/PC-16/2005 dt. 26.09.2007) and Dr. P. Manisankar wishes to thank UGC for providing financial assistance to Department of Industrial Chemistry.

\section{References}

1. Iijima, S.; Nature 1991, 354, 56.

2. Lin, K.; Xu, Y.; He, G.; Wang, X.; Mater. Chem. Phys. 2006, 99, 190.

3. Baughman, R. H.; Cui, C.; Zakhidov, A. A.; Iqbal, Z.; Barisci, J. N.; Spinks, G. M.; Wallace, G. G.; Mazzoldi, A.; Rossi, D. D.; Rinzler, A. G.; Jaschinski, O.; Roth, S.; Kertesz, M.; Science 1999, 284, 1340.

4. Wei, C.; Dai, L.; Roy, A.; Tolle, T. B.; J. Am. Chem. Soc. 2006, $128,1412$.

5. Yogeswaran, U.; Thiagarajan, S.; Chen, S. M.; Anal. Biochem. 2007, 365, 122.

6. Zeng, J. X.; Gao, X. H.; Wei, W. Z.; Zhai, X. R.; Yin, J.; Wu, L.; Liu, X. Y.; Liu, K.; Gong, S. G.; Sens. Actuators B 2007, 120, 595 . 
7. Xu, J. M.; Wang, Y. P.; Xian, Y.Z.; Jin, L. T.; Tanaka, K.; Talanta 2003, 60, 1123.

8. Zeng, B. Z.; Wei, S. H.; Xiao, F.; Zhao, F. Q.; Sens. Actuators B 2006, 115, 240.

9. Wang, G. F.; Hu, N. J.; Wang, W.; Li, P. C.; Gu, H. C.; Fang, B.; Electroanalysis 2007, 19, 2329.

10. Zhao, Y. D.; Zhang, W. D.; Chen, H.; Luo, Q. M.; Talanta 2002, $58,529$.

11. Wang, S. G.; Zhang, Q.; Wang, R.; Yoon, S. F.; Ahn, J.; Yang, D. J.; Tian, J. Z.; Li, J. Q.; Zhou, Q.; Electrochem. Commun. 2003, 5, 800 .

12. Wang, Z. H.; Xiao, S. F.; Chen, Y.; J. Electroanal. Chem. 2006, 589, 237.

13. Li, Q. W.; Zhang, J.; Yan, H.; He, M. S.; Liu, Z. F.; Carbon 2004, 42, 287.

14. Sandler, J.; Shaffer, M. S. P.; Prasse, T.; Bauhofer, W.; Schulte, K.; Winder, A. H.; Polymer 1999, 40, 5967.

15. Wang, Z. J.; Yuan, J. H.; Li, M. Y.; Han, D. X.; Zhang, Y. J.; Shen, Y. F.; Niu, L.; Ivaska, A.; J. Electroanal. Chem. 2007, 599, 121.

16. Wang, J.; Musameh, M.; Anal. Chim. Acta 2005, 539, 209.

17. Tsai, Y. C.; Li, S. C.; Liao, S. W.; Biosens. Bioelectron. 2006, 22, 495.

18. San, S. E.; Yerli, Y.; Okutan, M.; Yilmaz, F.; Gunaydin, O.; Hames, Y.; Mater. Sci. Eng. B 2007, 138, 284.

19. Guo, M. L.; Chen, J. H.; Li, J.; Tao, B.; Yao, S. Z.; Anal. Chim. Acta 2005, 532, 71.

20. Gao, M.; Huang, S.; Dai, L.; Wallace, G.; Gao, R.; Wang, Z.; Angew. Chem. Int. Ed. Engl. 2000, 39, 3664.

21. Coleman, J. N.; Curran, S.; Dalton, A. B.; Davey, A. P.; McCarthy, B.; Blau, W.; Barklie, R. C.; Synth. Met. 1999, 102, 1174.

22. Wang, J.; Li, R.; Anal. Chem. 1989, 61, 2809.

23. Agui, L.; Serra, B.; Yanez-Sedeno, P.; Reviejo, A. J.; Pingarron, J. M.; Electroanalysis 2001, 13, 1231.

24. Mark Jr, H. B.; Atta, N.; Ma, Y. L.; Petticrew, K. L.; Zimmer, H.; Shi, Y.; Lunsford, S. K.; Rubinson, J. F.; Galal, A.; Bioelectrochem. Bioenerg. 1995, 38, 229.
25. Atta, N. F.; Marawi, I.; Pettticrew, K. L.; Zimmer, H.; Mark Jr, H. B.; Galal, A.; J. Electroanal. Chem. 1996, 408, 47.

26. Galal, A.; J. Solid State Electrochem. 1998, $2,7$.

27. Wang, H. S.; Huang, D. Q.; Liu, R. M.; J. Electroanal. Chem. 2004, 570, 83.

28. Augi, L.; Gonzalez-Cortes, A.; Yanez-Sedeno, P.; Pingarron, J. M.; Anal. Chim. Acta 1999, 401, 145.

29. Jaraba, P.; Augi, L.; Yanez-Sedeno, P.; Pingarron, J. M.; Electrochim. Acta 1998, 43, 3555.

30. Armentia, C. L.; Sampedro, C.; Goicolea, M. A.; Balugera, Z. G.; Rodriguez, E.; Barrio, R. J.; Electroanalysis 1999, 11, 1222.

31. Wang, H-S.; Li, T-H.; Jia, W-L.; Xu, H-Y.; Biosens. Bioelectron. 2006, 22, 664.

32. Augi, L.; Pena-farfal, C.; Yanez-Sedeno, P.; Pingarron, J. M.; Electrochim. Acta 2007, 52, 7946.

33. Miller, G. T.; Sustaining the Earth, 6th edition, Thompson Learning, Inc. Pacific Grove, California. 2004, 211.

34. Manisankar, P.; Viswanathan, S.; Mercy Pusphalatha, A.; Rani, C.; Anal. Chim. Acta 2005, 528, 157.

35. Chu, X-G.; Hu, X -Z.; Yao, H -Y.; J. Chromatogr. A 2005, 1063 , 201.

36. Huang, Z.; Li, Y.; Chen, B.; Yao, S.; J. Chromatogr. B 2007, $853,154$.

37. Zhang, M.; Huang, J.; Wei, C.; Yu, B.; Yang, X.; Chen, X.; Talanta 2008, 74, 599.

38. Gonzalez-Rodriguez, R. M.; Rial-Otero, R.; Cancho-Grande, B.; Simal-Gandara,J.; J. Chromatogr. A 2008,1196, 100.

39. Mou, R-X.; Chen, M-X.; Zhi, J-L.; J. Chromatogr. B 2008, 875, 437.

40. Patil, S. H.; Banerjee, K.; Dasgupta, S.; Oulkar, D. P.; Patil, S. B.; Jadhav, M. R.; Savant, R. H.; Adsule, P. G.; Deshmukh, M. B.; J. Chromatogr. A 2009, 1216, 2307.

41. Li, H-P.; Lin, C-H.; Jen, J-F.; Talanta 2009, 79, 466.

42. Dagnaca, T.; Garcia-Chao, M.; Pulleiro, P.; Garcia-Jares, C.; Llompart, M.; J. Chromatogr. A 2009, 1216, 3702.

Submitted: January 4, 2010 Published online: January 20, 2011 